\title{
Water Quality Analysis and Countermeasure Research of Centralized Rural Drinking Water Project in Zhejiang Province

\author{
XU Dong ${ }^{1}$,WANG Peifeng ${ }^{1}$, Shen Biwen ${ }^{1}$, Lin Rui ${ }^{2}$
}

(1.Zhejiang University of Water Resources and Electric Power, Hangzhou, 310018, China;

2.Bureau of Hydrology in Zhejiang Province, Hangzhou, 310009, China)

Keywords: rural drinking water; centralized water supply; monitoring ability

\begin{abstract}
Objective: The water quality and sanitary conditions of centralized rural drinking water project in Zhejiang Province is analyzed, it can provide the scientific basis for rural water improvement and the government administrative department makes decision. Method: In 2013, 40 monitoring Counties in Zhejiang province were selected as the research objectives, in the high water period and in low water period, each sampling 1 time, 3973 copies of the centralized water samples were collected, and 20 indicators were detected. On each monitoring point, the selection of water source and the water purification process were investigated. Results: Most of the centralized rural drinking water projects in Zhejiang province take the surface water as water source, accounting for $71.25 \%, 7908$ waterworks take the whole clean water processing, accounting for only $16.21 \%$, $25.49 \%$ of the projects have not taken any measures. The centralized drinking water quality and health monitoring researched, and the total qualified rate is $46.72 \%$. In the low water period and high water period, the qualified rates are respectively $58.57 \%$ and $35.03 \%$, the main exceed the standard indicators are total coliforms and thermotolerant coliform bacteria and other microbial indicators, the turbidity and other sensory indicators are excess. Conclusions: The water quality monitoring qualified rate is low of Zhejiang province rural drinking water projects, and the hidden safety of drinking water is serious. We propose to strengthen the monitoring work and operation management, water facilities need to be improved, the construction of coordination mechanism among the departments needs to be enhanced, and the safety of rural drinking water should be ensured.
\end{abstract}

\section{Introduction}

Rural drinking water safety is directly related to the life and health of millions of farmers. Rural water supply project is the key work of balancing the urban and rural development, improving the quality of life of farmers, and promoting the rural economic and social development. The rural drinking water project is the important infrastructure in the country of China ${ }^{[1]}$. It is also the main part of rural public health system construction. The water quality and sanitary conditions of centralized rural drinking water project in Zhejiang Province is analyzed, it can provide the scientific basis for rural water improvement and the government administrative department makes decision $^{[2]}$. In 2013, 40 monitoring Counties in Zhejiang province were selected as the research objectives, the comprehensive investigation and analysis of water quality monitoring were taken, and the analysis reports and results are expressed as follows.

\section{Contents and methods}

\subsection{Selection of monitoring spots}

According to the geographical environment, social and economic conditions, 40 monitoring Counties are selected as the monitoring spots, there are 7908 waterworks. According to water types, water treatment process, and water supply scale, layering random sampling is taken, 1000 centralized water supply spots in rural areas are determined ${ }^{[3-5]}$.

\subsection{Investigation and sampling method}

According to the requirements of "Zhejiang province rural drinking water hygiene monitoring technology program", through the methods such as information access, on-site investigation, etc, the unified survey table is filled in. On each monitoring point, the selection of water source, water purification process is investigated. In the high water period and in low water period, waterworks are investigated on the spot, the water sanitary quality detection is taken, each monitoring point is provided with 2 sampling points (Outlet has 1 sampling point, and the terminal has 1 sampling point), there are total of 1000 sampling points. The water quality monitoring indicators include microbial indicators, toxicological indicators, sensory indicators and general chemical indicators, total of 20 indicators. There are total of 3973 centralized samples.

The collection, preservation and test of water samples are taken in accordance with GB /T5750-2006 "drinking water standard test method". According to GB5749-2006 "drinking water health standards", the evaluation is formed, all the test items are in accordance with GB5749-2006 "drinking water health standards", it is taken as the 
standard for judging the sample is qualified, of which one and above indicators do not meet the standard, judging the sample is unqualified.

\subsection{Data processing and analysis}

After the data information is verified, the data are read to the MS Excel, SPSS 10.0 and DUNCAN software are used for the statistical processing and analysis.

\section{Results}

\subsection{Types of water source}

Most of the centralized rural drinking water projects in Zhejiang province take the surface water as water source, accounting for $71.25 \%$. There are 2273 waterworks take the groundwater as the water source, accounted for $28.75 \%$, the source of water distributions of centralized water supply in Rural County Waterworks are shown in Table 1.

Table 1. Water source situation of rural county waterworks on monitoring points

\begin{tabular}{cccc}
\hline \multicolumn{2}{c}{ Types of water source } & Waterworks & Proportion (\%) \\
\hline \multirow{4}{*}{ Surface } & River water & 134 & 1.69 \\
water & Lake water & 13 & 0.16 \\
& Reservoir water & 1998 & 25.27 \\
& Pond ditch water & 170 & 2.15 \\
& Stream water & 2994 & 37.86 \\
& Else & 326 & 4.12 \\
& Subtotal & 5635 & 71.25 \\
\hline \multirow{4}{*}{ Groundwater } & Deep well water & 624 & 7.89 \\
& Spring water & 1122 & 14.19 \\
& Shallow well water & 527 & 6.67 \\
& Subtotal & 2273 & 28.75 \\
& Total & 7908 & 100.00 \\
\hline
\end{tabular}

\subsection{Water purification process}

In 7908 waterworks, 1282 waterworks take the complete clean water processing, accounting for only $16.21 \%$. 3576 waterworks take sedimentation and filtration method for water clean processing, accounting for 45.22\%.1034 waterworks only take disinfection method for clean water processing, 2016 waterworks have not taken any processing procedures, accounting for $25.49 \%$. From the survey results, there are still part of the centralized water supply in rural areas do not have any water treatment process, using the direct water supply mode, it is not safe. The investigation results are shown in Table 2.

Table 2. Clean water processing investigation results of monitoring points

3.3

\begin{tabular}{cccccc}
\hline $\begin{array}{c}\text { Water } \\
\text { processing } \\
\text { methods }\end{array}$ & $\begin{array}{c}\text { Complete } \\
\text { processing }\end{array}$ & $\begin{array}{c}\text { Sedimentation } \\
\text { and filtration }\end{array}$ & $\begin{array}{c}\text { Only } \\
\text { disinfection }\end{array}$ & $\begin{array}{c}\text { Without } \\
\text { processing }\end{array}$ & Total \\
\hline $\begin{array}{c}\text { Number of } \\
\text { Waterworks } \\
\text { Proportion } \\
(\%)\end{array}$ & 1282 & 3576 & 1034 & 2016 & 7908 \\
\hline
\end{tabular}

\section{Water quality status}

The centralized drinking water quality and health monitoring researched, and the total qualified rate is $46.72 \%$. In the low water period and high water period, the qualified rates are respectively $58.57 \%$ and $35.03 \%$, the qualified rate of waterworks outlet is $44.60 \%$, the qualified rate of water terminal is $48.82 \%$. The results are shown in Table 3. Overall, the qualified rate in dry season is higher than the abundant water period, and the qualified rate of terminal water is higher than the outlet water. This result is mainly because that water treatment process is not perfect of the rural drinking water safety, disinfection equipment configuration has low rate, and the disinfection facilities do not use norms and so on. The broad masses of peasants need to improve the drinking water situation, improve the quality of life.

From the rural centralized water supply factory monitoring results, according to all the indicators, the lowest standard rate indicator is the total coliform, it is $57.44 \%$. The rate of thermotolerant coliform bacteria is $61.92 \%$, and the turbidity is $86.03 \%$. From the above three indicators, the water quality is bad, and it affects the rural drinking water safety, it has close relationship to the configuration and usage of disinfection facilities. 
The investigation and research results are described in Table 4 and Table 5.

Table 3. Overall evaluation of water quality and health monitoring of centralized water supply

\begin{tabular}{|c|c|c|c|c|c|c|c|c|c|}
\hline \multirow[b]{2}{*}{$\begin{array}{c}\text { Overall } \\
\text { evaluation }\end{array}$} & \multicolumn{3}{|c|}{ Outlet water of waterworks } & \multicolumn{3}{|c|}{ Terminal water } & \multicolumn{3}{|c|}{ Total } \\
\hline & $\begin{array}{c}\text { Water } \\
\text { samples }\end{array}$ & $\begin{array}{c}\text { Qualifie } \\
\text { d } \\
\text { number }\end{array}$ & $\begin{array}{c}\text { Qualifie } \\
\text { d rate } \\
(\%)\end{array}$ & $\begin{array}{l}\text { Water } \\
\text { samples }\end{array}$ & $\begin{array}{c}\text { Qualifie } \\
\text { d } \\
\text { number }\end{array}$ & $\begin{array}{c}\text { Qualifie } \\
\text { d rate } \\
(\%)\end{array}$ & $\begin{array}{c}\text { Water } \\
\text { samples }\end{array}$ & $\begin{array}{c}\text { Qualifie } \\
\text { d } \\
\text { number }\end{array}$ & $\begin{array}{c}\text { Qualifie } \\
\text { d rate } \\
(\%)\end{array}$ \\
\hline $\begin{array}{l}\text { Low water } \\
\text { period }\end{array}$ & 984 & 531 & 53.96 & 988 & 624 & 63.16 & 1972 & 1155 & 58.57 \\
\hline $\begin{array}{l}\text { High water } \\
\text { period }\end{array}$ & 998 & 353 & 35.37 & 1003 & 348 & 35.03 & 2001 & 701 & 35.03 \\
\hline Total & 1982 & 884 & 44.60 & 1991 & 972 & 48.82 & 3973 & 1856 & 46.72 \\
\hline
\end{tabular}

Table 4 Water single indicator evaluation in low water period

\begin{tabular}{cccccccccc}
\hline & \multicolumn{3}{c}{ Outlet water } & \multicolumn{3}{c}{ Terminal water } & \multicolumn{3}{c}{ Total } \\
\cline { 2 - 9 } Indicators & $\begin{array}{c}\text { Water } \\
\text { sample } \\
\text { s }\end{array}$ & $\begin{array}{c}\text { Qualifie } \\
\text { d } \\
\text { number }\end{array}$ & $\begin{array}{c}\text { Qualifie } \\
\text { d rate } \\
(\%)\end{array}$ & $\begin{array}{c}\text { Water } \\
\text { sample } \\
\text { s }\end{array}$ & $\begin{array}{c}\text { Qualifie } \\
\text { d } \\
\text { number }\end{array}$ & $\begin{array}{c}\text { Qualifie } \\
\text { d rate } \\
(\%)\end{array}$ & $\begin{array}{c}\text { Water } \\
\text { sample } \\
\text { s }\end{array}$ & $\begin{array}{c}\text { Qualifie } \\
\text { d } \\
\text { number }\end{array}$ & $\begin{array}{c}\text { Qualifie } \\
\text { d rate } \\
(\%)\end{array}$ \\
\hline Chroma & 984 & 982 & 99.80 & 988 & 987 & 99.90 & 1972 & 1969 & 99.85 \\
Turbidity & 984 & 852 & 86.59 & 988 & 874 & 88.46 & 1972 & 1726 & 87.53 \\
Smell taste & 984 & 983 & 99.90 & 988 & 984 & 99.60 & 1972 & 1967 & 99.75 \\
Visible & 984 & 911 & 92.58 & 988 & 918 & 92.91 & 1972 & 1829 & 92.75 \\
pH & 984 & 949 & 96.44 & 988 & 951 & 96.26 & 1972 & 1900 & 96.35 \\
Iron & 984 & 977 & 99.29 & 988 & 979 & 99.09 & 1972 & 1956 & 99.19 \\
Manganese & 984 & 981 & 99.70 & 988 & 985 & 99.70 & 1972 & 1966 & 99.70 \\
Chloride & 984 & 984 & 100.00 & 988 & 988 & 100.00 & 1972 & 1972 & 100.00 \\
Sulfate & 984 & 980 & 99.59 & 988 & 984 & 99.60 & 1972 & 1964 & 99.59 \\
Solubility & 984 & 984 & 100.00 & 988 & 988 & 100.00 & 1972 & 1972 & 100.00 \\
Hardness & 984 & 983 & 99.90 & 988 & 988 & 100.00 & 1972 & 1971 & 99.95 \\
Oxygen & 984 & 983 & 99.90 & 988 & 987 & 99.90 & 1972 & 1970 & 99.90 \\
Ammonia & 984 & 980 & 99.59 & 988 & 985 & 99.70 & 1972 & 1965 & 99.65 \\
Fluoride & 984 & 981 & 99.70 & 988 & 985 & 99.70 & 1972 & 1966 & 99.70 \\
Arsenic & 984 & 984 & 100.00 & 988 & 988 & 100.00 & 1972 & 1972 & 100.00 \\
Nitrate & 984 & 981 & 99.70 & 988 & 985 & 99.70 & 1972 & 1966 & 99.70 \\
Bacteria & 984 & 928 & 94.31 & 988 & 937 & 94.84 & 1972 & 1865 & 94.57 \\
Coliform & 984 & 675 & 68.60 & 988 & 663 & 67.11 & 1972 & 1338 & 67.85 \\
Thermotolera & 984 & 723 & 73.48 & 988 & 714 & 72.27 & 1972 & 1437 & 72.87 \\
Residual & 268 & 142 & 53.38 & 260 & 162 & 62.31 & 528 & 304 & 57.58 \\
Chlorine & 177 & 121 & 68.36 & 181 & 121 & 66.85 & 358 & 242 & 67.60 \\
Total & 19141 & 18064 & 94.37 & 19213 & 18153 & 94.49 & 38354 & 36217 & 94.43 \\
\hline
\end{tabular}

Table 5. Water single indicator evaluation in high water period

\begin{tabular}{cccccccccc}
\hline & \multicolumn{3}{c}{ Outlet water } & \multicolumn{3}{c}{ Terminal water } & \multicolumn{3}{c}{ Total } \\
\cline { 2 - 10 } Indicators & $\begin{array}{c}\text { Water } \\
\text { samples }\end{array}$ & $\begin{array}{c}\text { Qualifi } \\
\text { ed } \\
\text { number }\end{array}$ & $\begin{array}{c}\text { Qualifie } \\
\text { d rate } \\
(\%)\end{array}$ & $\begin{array}{c}\text { Water } \\
\text { samples }\end{array}$ & $\begin{array}{c}\text { Qualifi } \\
\text { ed } \\
\text { number }\end{array}$ & $\begin{array}{c}\text { Qualifi } \\
\text { ed rate } \\
(\%)\end{array}$ & $\begin{array}{c}\text { Water } \\
\text { samples }\end{array}$ & $\begin{array}{c}\text { Qualifi } \\
\text { ed } \\
\text { number }\end{array}$ & $\begin{array}{c}\text { Qualifie } \\
\text { d rate } \\
(\%)\end{array}$ \\
\hline Chroma & 998 & 985 & 98.70 & 1003 & 993 & 99.00 & 2001 & 1978 & 98.85 \\
Turbidity & 998 & 838 & 83.97 & 1003 & 854 & 85.14 & 2001 & 1692 & 84.56 \\
Smell taste & 998 & 995 & 99.70 & 1003 & 1003 & 100.00 & 2001 & 1998 & 99.85 \\
Visible & 998 & 900 & 90.18 & 1003 & 918 & 91.53 & 2001 & 1818 & 90.85 \\
pH & 998 & 949 & 95.09 & 1003 & 960 & 95.71 & 2001 & 1909 & 95.40 \\
Iron & 998 & 984 & 98.60 & 1003 & 993 & 99.00 & 2001 & 1977 & 98.80
\end{tabular}




\begin{tabular}{cccccccccc} 
Manganese & 998 & 969 & 97.09 & 1003 & 982 & 97.91 & 2001 & 1951 & 97.50 \\
Chloride & 998 & 998 & 100.00 & 1003 & 525 & 100.00 & 2001 & 1523 & 76.11 \\
Sulfate & 998 & 525 & 100.00 & 1003 & 1003 & 100.00 & 2001 & 1528 & 76.36 \\
Solubility & 998 & 998 & 100.00 & 1003 & 1003 & 100.00 & 2001 & 2001 & 100.00 \\
Hardness & 998 & 997 & 99.90 & 1003 & 1002 & 99.00 & 2001 & 1999 & 99.90 \\
Oxygen & 998 & 994 & 99.60 & 1003 & 1002 & 99.90 & 2001 & 1996 & 99.75 \\
Ammonia & 998 & 986 & 98.80 & 1003 & 995 & 99.20 & 2001 & 1981 & 99.00 \\
Fluoride & 998 & 996 & 99.80 & 1003 & 1001 & 99.80 & 2001 & 1997 & 99.80 \\
Arsenic & 998 & 998 & 100.00 & 1003 & 1003 & 100.00 & 2001 & 2001 & 100.00 \\
Nitrate & 998 & 993 & 99.50 & 1003 & 1001 & 99.80 & 2001 & 1994 & 99.65 \\
Bacteria & 998 & 804 & 80.56 & 1003 & 790 & 78.76 & 2001 & 1594 & 79.66 \\
Coliform & 998 & 473 & 47.39 & 1003 & 471 & 46.96 & 2001 & 944 & 47.18 \\
Thermotoler & 998 & 515 & 51.60 & 1003 & 508 & 50.60 & 2001 & 1023 & 51.12 \\
Residual & 299 & 119 & 39.80 & 326 & 148 & 50.34 & 625 & 267 & 42.72 \\
Chlorine & 193 & 95 & 49.22 & 197 & 96 & 48.73 & 390 & 191 & 48.97 \\
Total & 19454 & 17111 & 87.96 & 19580 & 17251 & 88.11 & 39034 & 34362 & 88.03 \\
\hline
\end{tabular}

\section{Discussions and conclusions}

\subsection{Existing problems}

The survey results show that, the drinking water project in Zhejiang province has the water quality and safety problem, it is shown as the following aspects:

(1) The water quality monitoring qualified rate is low, for the 40 counties (cities, areas), the total qualified rate of water samples is $46.72 \%$.

(2) The microbial indicators exceed the standard, it is the main factor affecting the water quality, the main exceed the standard indicators are total coliforms and thermotolerant coliform bacteria and other microbial indicators, the turbidity and other sensory indicators exceed the norm.

(3) The water purification process and operation management level should be further improved, according to this monitoring, the complete processing of water purification only accounts for $16.21 \%$, and even $25.49 \%$ of the waterworks have not taken any measures, which is an important reason for water quality not up to standard.

\subsection{Countermeasures and suggestions}

(1) To strengthen the monitoring and management, monitoring funds should be abundant. The monitoring counties make the rural drinking water safety projects in the annual work plan. Actively strive for all levels of finance supporting funds, provide security monitoring with abundant funds, to ensure the completion of the task and the infrastructure construction.

(2) To strengthen the operation management of rural drinking water safety project. Strive to promote the rural drinking water safety project, increase the rural drinking water safety work funds and policy support. To strengthen the management of rural drinking water safety project technical guidance, staff training and supervision and management. Strengthen and improve the operation and management, build a number of water quality health management areas.

(3) To strengthen relevant contact and coordination of departments, strengthen the monitoring work and operation management, water facilities need to be improved, the construction of coordination mechanism among the departments needs to be enhanced. All the departments work together to ensure that the rural drinking water safety.

\section{References.}

[1] Rao Yutai,Yang fan. Network Intrusion Stir the Network Instability Control Methods of the Research[J]. Bulletin of Science and Technology, 2014, 30(1):185-188.

[2] WANG Hai-feng, LU Jun. Research and Simulation on Complex Electric Power Equipment Sudden Fault Diagnosis[J]. Computer Simulation, 2013, 30(3): 127-129.

[3] Chang YL, Lin TL: Network-based H.264/AVC whole frame loss visibility model and frame dropping methods[J]. IEEE Transactions on Image Processing, 2012, 21(8):3353-3363.

[4] Qinsheng Du, Baohua Jiang. Design and Implementation of the Embedded Based Web Camera System[J]. Journal of Software, 2012, 7(11), 2560-2566.

[5] H HARTENSTEIN, K P LABERTEAUX. A Tutorial Survey on Vehicular Ad Hoc Networks[J]. IEEE 
Communications Magazine, 2008, 46 (6):164-171. 